\title{
ДОСВІД ВИКЛАДАННЯ ІНОЗЕМНИМ СТУДЕНТАМ НА КАФЕДРІ ПРОПЕДЕВТИКИ ДИТЯЧИХ ХВОРОБ
}

\author{
Ю. М. Нечитайло, О. Г. Буряк, Д. Ю. Нечитайло
}

Буковинський державний медичний університет

\section{EXPERIENCE OF TEACHING FOR FOREIGN STUDENTS AT THE DEPARTMENT OF PROPAEDEUTICAL PEDIATRICS}

\author{
Yu. M. Nechytaylo, O. H. Buriak, D. Yu. Nechytaylo \\ Bukovynian State Medical University
}

\begin{abstract}
У статті розкривається досвід викладання пропедевтичної педіатрії на кафедрі пропедевтики дитячих хвороб у Буковинському державному медичному університеті за кредитно-модульною системою студентам 3 англомовною формою навчання. Описані основні методики, що застосовуються в процесі навчання, роль самостійної підготовки.
\end{abstract}

The article adduces the experience of teaching of Propaedeutic Pediatrics at the Department of Propaedeutic of Child's Diseases in Bukovynian State Medical University by the credit-modular system. Basic methods which are used in the process of studies, role of independent preparation, are described.

Вступ. Входження України до єдиного Європейського та світового освітнього простору вимагає модернізації системи вищої освіти України, яка є одним 3 найважливіших стратегічних завдань забезпечення якості підготовки фахівців на рівні міжнародних вимог [1]. На цьому підгрунті розвиток викладання медичних дисциплін у нашій країні стає адаптованим і узгодженим з процесами, що відбуваються в Європі [2].

Актуальною постає проблема вдосконалення методичних особливостей викладання медичних дисциплін, зокрема пропедевтичної педіатрії, студентаміноземцям в українських ВНЗ у контексті євроінтеграції освітніх послуг. Важливість зазначеної проблематики пов'язана з впровадженням Болонського процесу в Україні, залученням іноземного досвіду викладання та розширення спектра освітніх послуг, з активною комп'ютеризацією процесу навчання, а також особливостями застосування інноваційних навчальних методик [3].

Основна частина. Основною метою педагогічного процесу у вищому навчальному медичному закладі є підготовка висококваліфікованих медичних кадрів. Тим більше в наш час, коли гостро постає питання підготовки лікаря загальної практики. Це питання повинно вирішуватись всіма ланками навчання. Одна логічна дедуктивна система, яка $є$ результатом об'єднання всіх цих компонентів в єдине ціле і являє собою інтеграцію навчального процесу.
На кафедрі пропедевтики дитячих хвороб Буковинського державного медичного університету існує методичне забезпечення у вигляді матеріалів для підготовки до практичних занять, презентацій лекцій, методичних розробок для студентів, алгоритмів практичних навичок, наборів тестових завдань, методичних розробок для викладачів.

Орієнтуючись на сучасні тенденції, ми повинні розуміти, що інтеграція не може обмежуватись лише навчальним процесом. Самостійна робота студентів є невід'ємною іiї складовою. В цьому плані велику роль у підготовці до практичного заняття відіграє використання сервера дистанційного навчання університету в системі “Moodle". Наприклад, при вивченні англомовними студентами тематичного модуля "Ріст i розвиток дитини”, який має конкретні цілі: 1) знати місце пропедевтики педіатрії в системі загальної медицини; 2) знати принципи організації лікувальнопрофілактичної допомоги дітям; 3) знати правила санітарно-гігієнічного та протиепідемічного режимів у дитячих лікувально-профілактичних закладах; 4) трактувати критерії здоров'я дитини; 5) аналізувати основні статистичні показники діяльності лікувально-профілактичних закладів; 6) інтерпретувати історичні етапи розвитку педіатрії в Україні; 7) аналізувати особливості різних періодів дитячого віку, ми орієнтували увагу студентів на навчальний сайт, створений на сервері дистанційного навчання університе-

() Ю. М. Нечитайло, О. Г. Буряк, Д. Ю. Нечитайло 
ту, який абсолютно повністю відповідає всьому спектру необхідних знань для засвоєння даного модуля.

У системі навчання студентів-іноземців використання комп'ютерних технологій та Інтернет-ресурсів надає можливість займатись професійним саморозвитком у зручний для них час, а не як традиційно “за розкладом”. Кожний самостійно визначає для себе місце, тему роботи, що взагалі не впливає на звичайний ритм життя. 3 цієї позиції ми акцентуємо увагу на переваги широкого використання віртуальних підручників та лекційного матеріалу на сайті віртуальної бібліотеки.

Запитання проміжного та підсумкового тестового контролю знань студентів частково включаються до тем лекцій, та теоретичних курсів. Саме ці питання повинні бути цілеспрямовані на особливості подання теоретичного матеріалу студентам, особливо 3 англомовною формою навчання. Вищеперелічені прийоми вивчення теоретичного матеріалу дають можливість їм максимально застосовувати отримані знання при вирішенні тестових завдань.

Якість результатів навчання, можливість їх застосовувати при вивченні інших дисциплін та в повсякденній професійній діяльності є нашим пріоритетним напрямком по застосуванню тестового контролю. Перевірка рівня знань студентів за допомогою тестів проводиться як по закінченню всього курсу пропедевтичної педіатрії, так і після вивчення окремих розділів дисципліни. Саме така методика дає змогу максимально об'єктивно оцінити рівень теоретичних знань кожного студента.

Проте основна частина студентів, готуючись до занять, користується лише матеріалами, які наведені на сервері дистанційного навчання або підручниками, незважаючи на те, що підготовка передбачає використання наукових статей зі спеціальності і даних з різноманітних сайтів Інтернету. Зокрема, відсоток правильних відповідей різко падає, коли питання складені не на основі підручника або віртуальних навчальних матеріалів, а базуються на лекційному матеріалі.

На кафедрі створено банк тестових завдань 3 дисципліни "Пропедевтична педіатрія" для оцінки навчальних досягнень студентів-іноземців 3 курсу. Для цього були використані багатовибіркові тестові завдання, що складаються з умови та списку варіантів відповідей, з яких екзаменований мусить вибрати найбільш правильну відповідь. Тест складається 3 описання певної проблеми, яка ставиться перед екзаменованим, і відповідно варіантів відповідей, що є правдоподібними і відповідають одній предметній сфері. У більшості міжнародних тестових системах даний формат є найбільш уживаним, тому що забезпечує найменшу тестову невалідність і достатню діагностичну спроможність. Кафедра проводить періодичну оцінку валідності тестів і замінює тести, на які жоден із студентів не зміг дати відповідь, на легші, на які відповідали практично всі студенти.

Спираючись на те, що основи вивчення навчальної дисципліни “Дитячі хвороби” починаються саме 3 вивчення пропедевтичної педіатрії, підхід до викладання матеріалу повинен бути по-особливому своєрідним. Пропедевтика є не тільки вступом до педіатрії, а й зв’ язуючою ланкою викладання теоретичних і клінічних дисциплін.

Оволодіння практичними навичками, на думку працівників кафедри, є дуже важливими, тому їм приділяється велика увага. Засвоєння знань на практиці розподілені за темами модулів. Для правильного розуміння спочатку методика практичної навички пояснюється, а вже потім демонструється алгоритм їі виконання. На практичному занятті весь процес та рівень засвоєння знань пильно контролюється викладачами. Студенти зобов' язані проводити вечірні чергування в стаціонарі клінічної бази кафедри, для більш ретельного засвоєння практичного матеріалу. 3'ясування незрозумілих моментів, удосконалення навичок на практиці проводиться під час самостійної роботи студентів, в кількості 55 годин, які передбачені навчальною програмою.

Рівень оволодіння практичними навичками оцінюється не тільки з точки зору теоретичного знання, а й виконання іiі на практиці безпосередньо біля ліжка хворого під контролем викладача.

Під час написання академічної історії хвороби студенти мають найкращу можливість засвоїти практичні навички. Професійне володіння викладачами англійською є обов'язковим, особливо під час проведення занять 3 англомовним студентами, які мають змогу отримати вичерпні відповіді на ті чи інші запитання, які в них виникли, зрозумілою для них мовою.

Саме завдяки самостійній роботі студентів, при підготовці до занять в домашніх умовах, активності на практичних заняттях, курації хворих з наступним написанням історії хвороби в майбутнього лікаря формується прагнення до постійного самовдосконалення, розвивається клінічне мислення, стимулюється відновлення знань з фундаментальних дисциплін.

Оскільки відпрацювання пропущених занять на відробках не відповідають повноцінному практичному заняттю, на кафедральних нарадах постійно йде обговорення рівня академічної успішності та вироб- 


\section{ВДОСКОНАЛЕННЯ ВИЩОЇ МЕДИЧНОЇ ОСВІТИ}

ничої дисципліни студентів-іноземців. Відповідно, це має свої причини, а саме:

- переважна кількість іноземних студентів 3' являються на відробки за 2-3 тижні до складання модульного контролю;

- не в повному обсязі дають відповідь на запитання програми;

- нерідко студенти приходять погано підготовленими;

- якість написання рефератів з пропущених лекцій низька, і не відповідає, в повному обсязі, навчальній програмі;

- найголовніше - на відробітках важко створити умови для повноцінного набуття практичних навичок.

Внаслідок цього студенти, які мають велику кількість пропущених занять, не засвоюють елементарні практичні навички та отримують незадовільні оцінки під час складання модульного контролю.

Однією з найбільших перешкод, яка постає при роботі з студентами-іноземцями, є недостатнє їх володіння українською мовою, що необхідно при роботі 3 пацієнтами в стаціонарі. Слабкий рівень знань української мови, малий лексичний запас $є$ недостатнім для спілкування з пацієнтами і засвоєння повною мірою методики збирання анамнезу при самостійній роботі студента.

Висновок. В умовах кредитно-модульної системи організація навчального процесу серед іноземних студентів має свої особливості. Введення кредитномодульної системи спонукає студентів систематично готуватися до занять, а використання новітніх технологій системи дистанційного навчання дає можливість ефективно підвищити якість навчального процесу, збільшити рівень інформованості та підготовки студентів, оволодіти сучасними комп'ютерними технологіями роботи, індивідуалізувати та систематизувати навчання, підвищити вміння студентів працювати з різними джерелами інформації, що є необхідною умовою для подальшого зростання професійних якостей майбутнього лікаря. Саме підвищення ролі самостійної підготовки дає можливість раціонально організувати та збільшити ефективність навчання іноземних студентів-медиків.

Перспективи подальших досліджень у даному напрямку ми вбачаємо в пошуках нових форм оптимізації практично-орієнтованого викладання пропедевтичної педіатрії.

\section{Література}

1. Результати впровадження інноваційних технологій навчання за кредитно-модульною системою у Вінницькому національному медичному університеті ім. М. І. Пирогова / В. М. Мороз, Ю. Й. Гумінський, Т. Л. Полеся, Л. В. Фоміна // Інноваційні методики викладання в сучасній вищій освіті : навч.-метод. конф., 7 квіт. 2011 р. : тези допов. Вінниця, 2011.-С. 3-8.

2. Бойків А. Б. Досвід впровадження кредитно-модульної системи організації навчального процесу з пропедевтики

ортопедичної стоматології / А. Б. Бойків // Медична освіта. -2011.-№ 1.-С. 55-57.

3. Нечитайло Д. Ю. Особливості викладання пропедевтичної педіатрії іноземним студентам на англійській мові / Д. Ю. Нечитайло, О. Г. Буряк // Актуальні питання підготовки медичних та фармацевтичних фахівців у контексті європейської освітньої інтеграції : навч.-метод. конф., 20 квіт. 2011 р. : тези допов. - Чернівці, 2011. -С. 159. 